\title{
NATIONAL SURVEY EVIDENCE ON DISASTERS AND RELIEF: RISK BELIEFS, SELF-INTEREST, AND COMPASSION
}

\author{
W. Kip Viscusi \\ Richard J. Zeckhauser \\ Working Paper 12582 \\ http://www.nber.org/papers/w12582
NATIONAL BUREAU OF ECONOMIC RESEARCH
1050 Massachusetts Avenue
Cambridge, MA 02138
October 2006

\begin{abstract}
Alison DelRossi provided thoughtful guidance on our empirical analysis, Miriam Avins edited skillfully, and Nils Wernerfelt provided able research assistance. The views expressed herein are those of the author(s) and do not necessarily reflect the views of the National Bureau of Economic Research.

(C) 2006 by W. Kip Viscusi and Richard J. Zeckhauser. All rights reserved. Short sections of text, not to exceed two paragraphs, may be quoted without explicit permission provided that full credit, including (C) notice, is given to the source.
\end{abstract}


National Survey Evidence on Disasters and Relief: Risk Beliefs, Self-Interest, and Compassion W. Kip Viscusi and Richard J. Zeckhauser

NBER Working Paper No. 12582

October 2006

JEL No. D80,D81,H53,Q54

\author{
W. Kip Viscusi \\ Vanderbilt Law School \\ 131 21st Avenue South \\ Nashville, TN 37203-1181 \\ and NBER \\ kip.viscusi@ vanderbilt.edu \\ Richard J. Zeckhauser \\ John F. Kennedy School of Government \\ Harvard University \\ 79 John F. Kennedy Street \\ Cambridge, MA 02138 \\ and NBER \\ richard_zeckhauser@harvard.edu
}

ABSTRACT

A nationally representative sample of respondents estimated their fatality risks from four types of natural disasters, and indicated whether they favored governmental disaster relief. For all hazards, including auto accident risks, most respondents assessed their risks as being below average, with one-third assessing them as average. Individuals from high-risk states, or with experience with disasters, estimate risks higher, though by less than reasonable calculations require. Four-fifths of our respondents favor government relief for disaster victims, but only one-third do for victims in high-risk areas. Individuals who perceive themselves at higher risk are more supportive of government assistance. 
The United States has experienced its greatest natural and man-made disasters in recent years. In 2005, Hurricane Katrina led to the largest level of insured losses to property in the history of the United States. The 9/11/2001 attack on the World Trade Center, the Pentagon, and four airliners was by far the most devastating terrorism attack ever on the nation. Each event seared the nation's psyche.

How people perceive and respond to these disasters is of fundamental interest. To the extent that losses can be reduced through self-protection or self-insurance, people's risk beliefs will affect the extent to which they will undertake measures to reduce their losses. Natural disasters and other "acts of God" are not totally unanticipated and unpreventable. Those who build a beachfront home in a hurricane zone are exposed to much greater risk of hurricane damage than those who live inland. ${ }^{1}$ Protection against terrorism risks is less subject to individual control, though maintaining an adequate life insurance policy can reduce the economic deprivation to one's survivors. Following the 9/11 terrorism attack and recent natural disasters, the government made tremendous efforts to aid and rebuild. Public perceptions of the desirability of such assistance will govern the degree of public support for post-disaster aid.

This paper reports on evidence from an original national survey that focused on the public's perception of natural disaster and terrorism risks and the degree of support for different policy interventions. How do people perceive the risks of disasters? Do

\footnotetext{
${ }^{1}$ In a recent statement, ten climate experts who disagree about global warming observed that " "the main hurricane problem facing the United States'...is an ongoing 'lemming-like march to the sea' in the form of unabated coastal development in vulnerable places, and in the lack of changes in government policies and corporate and individual behavior that are driving the trend” (Revkin 2006).
} 
these perceptions vary in a plausible manner with actual risk levels based on information gleaned from their geographic location and personal experience?

What types of government relief policies do people favor, and in what circumstances? What is the source of such preferences? Are they governed by selfinterest with a concern for precedent, implying that people at higher risk would be more generous? Or does compassion play the predominant role? We use the term compassion, rather than altruism, when individuals are willing to assist others who have suffered significant losses, because the preference is more circumscribed than merely helping those who are worse off, perhaps because of weak job skills. And where people are compassionate, is there a concern for moral hazard, implying that their willingness to help would be tempered by an efficiency consideration, namely not to provide an incentive to locate in high-risk areas? Differences in the extent to which the public supports relief efforts of different kinds in New Orleans have led to months in which such efforts ground to a halt due to a lack of policy clarity on which areas of the city should be rebuilt and which should not. Rebuilding the high-risk areas is inefficient because it generates the prospect of either excess expenditures on assets that need protection, or substantial future expected losses accompanied by inevitable pressures for continued bailouts at the public's expense. Failure to rebuild these areas is a politically charged issue primarily because the poor, black segments of the New Orleans populations are concentrated in areas at greater risk, which produces lower real estate values and more affordable living.

To explore the public's views on such risks and different relief policies, we designed and administered a major national survey. Section 1 briefly summarizes the 
nationally representative sample used for our survey and describes the survey instrument. Our results provide a unique, detailed perspective on disaster risks. We compare natural disasters with both automobile accident risks and terrorism risks to put our results on natural disasters in perspective. Section 2 examines respondents' beliefs about different risks and the determinants of these risk beliefs. We find that most people rate themselves as being of average or below-average risk irrespective of the risk considered. There are, however, important differences in risk beliefs across respondents and types of risk. Section 3 analyzes respondents' beliefs about how government should respond to these hazards. As one might expect, we find evidence of considerable self-interest, with people living in high natural disaster risk or terrorism risk areas being more supportive of aid for the hazards to which they are exposed. However, there is also evidence of tremendous compassion, though where relevant restrained by moral hazard concerns.

\section{Background Information on the Survey}

We designed and commissioned a survey consisting of a series of questions regarding respondents' risk beliefs and their attitudes toward various policy responses to disasters. Detailed personal characteristic and background questions were also included, to serve as covariates in our empirical analysis. The text of many of these survey questions is reported below in conjunction with the pertinent empirical results.

Our data were secured using a Web-based survey administered to a sample from the Knowledge Networks (KN) panel. We pre-tested the survey in March 2006, administering it to over 100 subjects. This pre-test employed identical questions to those analyzed in this paper. This enables an important contrast, since in early April 2006, 
shortly after the pre-test was completed and before our main test, major tornadoes hit the Southeast, particularly the Tennessee area. ${ }^{2}$ The final survey was administered April 11 to April 25, 2006 following these tornadoes.

Both the pretest and the final survey were administered by $\mathrm{KN}$ to a nationally representative sample of respondents age 18 and older. Respondents took the survey on their computer or Web TV. The survey takes about 20 minutes. The completion rate for the survey was 79 percent. While 1,135 surveys were at least partially completed, we focus on the 1,077 observations for which we have complete data on all variables of interest. Appendix Tables A.1 and A.2 summarize the sample characteristics and variable means and standard deviations.

The sample for the final survey mirrored the national adult population. For concreteness, we sometimes compare the weighted completed interviews and the Current Population Survey benchmarks for February 2006. ${ }^{3}$ Our sample divides evenly between men and women, a negligible 0.1 percent difference from the national average. Some of the age categories equal the national fractions; the largest difference is 0.2 percent for those age 18-29 and those 30-44. The racial breakdowns for blacks, whites, and Hispanics differ by no more than 0.1 percent from the national statistics. Each of the education categories likewise has a discrepancy of at most 0.1 percent from the national figures. The regional breakdowns are often identical to the national average, with the largest difference being that the sample has 0.2 percent fewer respondents from the

\footnotetext{
${ }^{2}$ See McFadden, Robert D., et al. (2006). “A Barrage of Storms Batters 8 States, Leaving Death and Debris.” New York Times, 4 April, Final Edition; Emery, Theo. (2006). "Digging Out from Deadly Tornadoes, Tennessee is Struck by More.” New York Times, 9 April, Final Edition.

${ }^{3}$ The sample is weighted to account for some minor deviations from an equal probability design. For example, the panel never includes more than one adult per household and includes only half of the potential panel participants contacted who had telephone numbers but for which KN could not find an address. The weighted completed interviews are very similar to the unweighted numbers-47.4 percent males unweighted and 48.1 percent males weighted.
} 
Midwest. In short, the sample tracks the national population breakdowns remarkably well. It is not a convenience sample but a true, nationally representative sample that meets the highest standards of representativeness.

\section{Risk Beliefs for Natural Disasters and Other Risks}

We start by exploring how people assess their risks from natural disasters. In doing so, we address comparable risk belief questions for auto accident risks and terrorism risks. These comparisons help put the natural disaster risks in perspective. Auto accident risks are precisely estimated, well-known hazards that have been the subject of numerous previous analyses. Indeed, auto accident risks often are the anchor given to respondents in risk belief surveys so that they can think sensibly about other risks in the survey. ${ }^{4}$ Terrorism risks provide a different basis of comparison with natural disasters because, like natural disasters, they too tend to be dramatic, low-probability events that are highly publicized. ${ }^{5}$ Unlike auto accident risks, they are poorly understood, causal mechanisms for them are widely debated, and risk assessments for them are highly diffuse. Moreover, whereas auto accident risk levels are influenced considerably by personal safety-related behavior, such as driving speed and drunk driving, terrorism risks tend to be beyond individual control. Natural disaster risks involve both some exogenous nature-related risk components as well as aspects of personal choice, such as picking an at-risk location.

Given our focus on three classes of risks of quite disparate magnitude and precision, the challenge in designing the survey was to develop risk belief questions that

\footnotetext{
${ }^{4}$ See Lichtenstein et al.(1978).

${ }^{5}$ There is a considerable literature on perception and responses to low probability events. For a review see Camerer and Kunreuther (1989) and Kunreuther and Pauly (2004).
} 
could be compared across these different hazards. While quantitative risk questions seem ideal, respondents often have difficulty in assessing probabilities as small as the risks of being killed by terrorists. For example, even if the terrorism attacks of 2001 were to be repeated annually, the fatality risk would be under $1 / 100,000$ per year for a random citizen. The annual fatality risks from natural disasters are much lower.

\subsection{Risk benchmarks, averages and medians, personal experience}

Even order of magnitude changes in current risk levels would be hard for most respondents to assess, i.e., to say whether their personal risk was one in ten thousand, or one in one million, or one in ten million or one hundred million. Accordingly, we asked respondents to compare their risk level from a danger to the average risk level of others. ${ }^{6}$

More specifically, the risk belief questions for auto accident risks, natural disaster risks, and terrorism risks took a common form. The question first provided information that would enable respondents to assess the average risk across the population. The question then asked respondents whether they considered their own risk to be above average, average, or below average. The specific text of these questions was as follows:

Many of the following questions will ask you to compare programs that reduce auto accident risks and other types of hazards. Each year just under 40,000 people in vehicles die in traffic accidents in the United States. On the average day about 100 people die due to traffic accidents. These risks are isolated deaths. Even for major accidents the number of people killed in a particular accident is not great. How would you rate your risk compared to the average driver?

I have an average fatality risk........................ 1 I have an above-average fatality risk.............. 2

\footnotetext{
${ }^{6}$ One approach to eliciting terrorism risk assessments that was used in Viscusi and Zeckhauser (2003) was to ask the total number of people who would be killed in the U.S. next year in terrorism attacks. But such questions would be influenced by anchoring effects in the current survey, which gives respondents information on the average number of deaths from each cause. Moreover, the risks vary by region, and the regional variation is of substantial interest and will not be reflected in the national estimates of fatalities.
} 
In contrast, natural disasters kill large numbers of people at the same time and are major national catastrophes. Hurricanes, floods, tornadoes, and earthquakes are major types of disasters. Hurricane Katrina killed over 1,000 people, and every year natural disasters kill over 100 people on average. How would you rate your risk of being killed by a natural disaster?

I have an average fatality risk...................... 1

I have an above-average fatality risk.............. 2

I have a below-average fatality risk................ 3

Natural disasters aren't the only risks that kill many people at the same time. Attacks by international terrorists also can cause a catastrophic number of deaths. The 9/11 terrorist attack killed 2,976 people. How would your risk from terrorists compare to the average American's?

I have an average fatality risk........................... 1

I have an above-average fatality risk................ 2

I have a below-average fatality risk............... 3

One danger arising from asking for comparisons with "average Americans" is that mathematically oriented respondents might recognize that risk levels are in fact highly skewed, with a small percent of the population at substantially elevated risk. Thus, $98 \%$ of the population may indeed be at below-average risk of a fatality from our four types of natural disasters, which tend to strike specific geographic areas. The real contrast one might have wished was with the American at median risk. But we recognized that asking that question would have confused most of our respondents. Moreover, the median risk value for the risks in this survey is zero or quite close to it, so that the median American reference point would not have been informative. Some respondents may have used at least some element of "median reasoning" when responding to our average question. We follow in a long tradition in asking about risk levels relative to the average. 
Our principal purpose in using our risk questions is to establish a comparative risk rating across different types of risk, thus putting the natural disaster risk beliefs into a more general risk perception context.

Auto accident risk questions asked in relative terms have become a staple in the optimism bias literature. Rethans (1979) first showed that the overwhelming majority of drivers considered themselves to face average or below-average risk. Some might interpret this result as implying that people are overoptimistic and underestimate the risk. However, it may be that due to the skewed nature of the risk distribution across the population, most people correctly conclude that they are below average in risk. Our questions, which provide people with numbers of deaths in the total population, may spur them to think in terms of means rather than medians. If this is true for automobiles, it is likely true for the other risks included in the survey.

For a variety of reasons, most respondents will view themselves as facing average or below-average risks. Few people may be willing to find fault with themselves and rate themselves as bad drivers. Some respondents also select "average” as their response to all such comparative questions posed in a complicated survey to move quickly to complete the survey. ${ }^{7}$ To the extent that respondents adopt "average" as their timeminimizing response to taking our survey, that strategy should affect all risk belief questions equivalently. Some analysts have also hypothesized that the below-average fatality risk responses to auto accident risk questions may reflect the degree to which people believe, perhaps incorrectly, that they can exercise control over the risk. It should also be noted that even when people rate themselves as being of below-average risk or

\footnotetext{
${ }^{7}$ Viscusi (2002) presents survey evidence indicating that some respondents consistently rate themselves as being average on many disparate dimensions - stress level, income, degree of worry, and a variety of health risks.
} 
average risk, survey evidence on consumer behavior indicates that people's actual costrisk tradeoff decisions do not reflect underestimation of the risk (Viscusi and Magat, 1987).

The reference points indicating fatality experience for each of the questions were chosen to be informative, but the contents are not exactly parallel because of the unique nature of the $9 / 11$ attack. The survey apprises respondents of the number of motorvehicle deaths per year and per day, the number of people killed by Hurricane Katrina and the average number killed annually by natural disasters, and the total number of deaths from the 9/11 terrorist attack.

Table 1 reports the distribution of responses for each of these risks. Consistent with the literature, averaging across the three risk categories, the great majority of respondents—92.4 percent—-believe that they face average or below-average fatality risks. ${ }^{8}$ These percentages vary only a modest amount across the risk categories-from 91.5 percent for automobile hazards to 93.5 percent for natural disasters, with terrorism risks in between at 92 percent. Just over half of all respondents believe that they face below-average risks, and 41.3 percent believe they face average risks. Natural disaster risks and terrorism risks involve little personal control but nevertheless have a higher percentage of respondents rating themselves as being of below-average risk. These patterns are inconsistent with the common explanation that risk belief patterns such as those exhibited in the auto accident context are due to overestimation of the degree of personal control and the accompanying unwillingness to find fault with one's own driving skills.

\footnotetext{
${ }^{8}$ See Weinstein and Klein (1996) for similar “optimistic” results.
} 
It is quite reasonable that the majority of respondents believe they face belowaverage fatality risks from natural disasters and terrorism attacks. If they recognize that risk levels are skewed, with a few people at substantially elevated risk. Most people do not live in earthquake zones, exposed beachfront areas in the Southeast, or tornado corridors. Their risks will be much lower than the quite substantial risks faced by the small fraction of people living in such high-risk locales. Similarly, risks from terrorist attacks are presumably quite low for most of the United States, notwithstanding the Department of Homeland Security’s ill-considered ranking that identifies more terrorism targets in Indiana than in New York. ${ }^{9}$

\subsection{Personal experience and risk beliefs}

Personal experience with a natural disaster may affect individual risk beliefs.

From the standpoint of rational Bayesian learning, one would expect assessed risks to rise after experiencing a natural disaster. The Availability Heuristic may also be at work, although the influences of rational and irrational influences are difficult to disentangle. ${ }^{10}$ The survey consequently included questions to ascertain whether the respondent had experienced a hurricane, flood, earthquake or tornado. Assuming they had not moved a substantial distance, personal experience should greatly increase people’s current risk estimates, as we show below.

Table 2 presents the cross tabulation of these disaster experiences with the corresponding risk beliefs. Notably, for these different categories of disasters from 282 to 321 people in the sample, or just under one-third, had experienced each of these risks.

\footnotetext{
${ }^{9}$ See Lipton, Eric. (2006). “Come One, Come All, Join the Terror Target List.” New York Times, 12 July.

${ }^{10}$ See Tversky and Kahneman (1974) for discussion of the Availability Heuristic.
} 
Table 2 organizes the data with information on those who did not experience the disaster in the first two columns and information on those who experienced the disaster in the final two columns. The distribution of the influence of these events differs somewhat by the particular disaster. Experiencing a hurricane or a tornado decreases the percentage who rate their risks below average by about 10 percent, but has a minimal effect on flood and earthquake perceptions. For each risk, having experience with it shifts perceived risk upwards.

We conducted Wilcoxen rank sum tests using the logical ordering below-average, then average, and then above-average. These tests yield z-statistics of 3.473 for having experienced a hurricane and 2.964 for having experienced a tornado. The comparable differences for having experienced a flood $(\mathrm{z}=0.869)$ or an earthquake $(\mathrm{z}=0.708)$ are not statistically significant. Somewhat strikingly, even after experiencing any of these disasters the percentage who rate their risks as being above average ranges from only 7.8 percent to 10.6 percent.

Personal information is probably a more telling indicator of risk than state of residence, since there is so much interstate variability in risk level. Nevertheless, identifying the high-risk states proves very telling. We identify the four high hurricane risk states: Florida, Louisiana, Mississippi, and Texas, ${ }^{11}$ which between them hold over 13 percent of respondents in our sample. The risk belief summary in Table 3 indicates that living in a hurricane state substantially alters risk beliefs. Based on the Wilcoxen rank sum test, these differences are highly significant $(\mathrm{z}=5.977)$. The percentage of people who view the fatality risk as being below-average is 24 percent lower, where this

\footnotetext{
${ }^{11}$ This listing is consistent with the insurance industry experiences reported by Swiss Re, as discussed in Born and Viscusi (2006), this issue.
} 
difference is distributed fairly evenly between the two remaining categories. The fact that not everybody in these states perceives an elevated risk is also not surprising because inland areas in, for example, Dallas, Texas are at much lower risk than the Texas average.

\subsection{The distribution of risk across states, Lorenz curves, and rational updates}

Our results show that individuals in higher risk states are more likely to place themselves in a higher risk category. But what would rational calculation show? To investigate this question, we looked at fatalities from each of our four categories of natural disasters over the past 50 years. We then computed fatalities per capita for each state, and produced what in effect is a Lorenz Curve for each type of disaster, and for automobile fatalities. The data for earthquakes and tornadoes is from 1950-1994, for autos from 1994-2004, and for floods from 1995-2004. That is, for each source of fatalities, we computed what percent of the population is required to produce what percent of the fatalities. Our per capita calculations used the 2000 census, which is obviously a gross simplification, since the national population has grown substantially. Counterbalancing this, fatalities per capita have mostly decreased over this period. The Lorenz curves for these five types of disasters are shown in Figure 1. Note that the curves for the natural disasters are highly bowed, implying that a small fraction of the population accounts for a large percentage of the fatalities, though some are much more bowed than others. Indeed, to account for half of the fatalities, you need the following percentages of the population: (1) hurricanes, $14 \%$, (2) floods, $22 \%$, (3) earthquakes, 1\%, (4) tornadoes, 9\%, and (5) auto accidents, 35\%. 


\section{Figure 1. Lorenz Curve for Five Risks}

\section{(state data)}

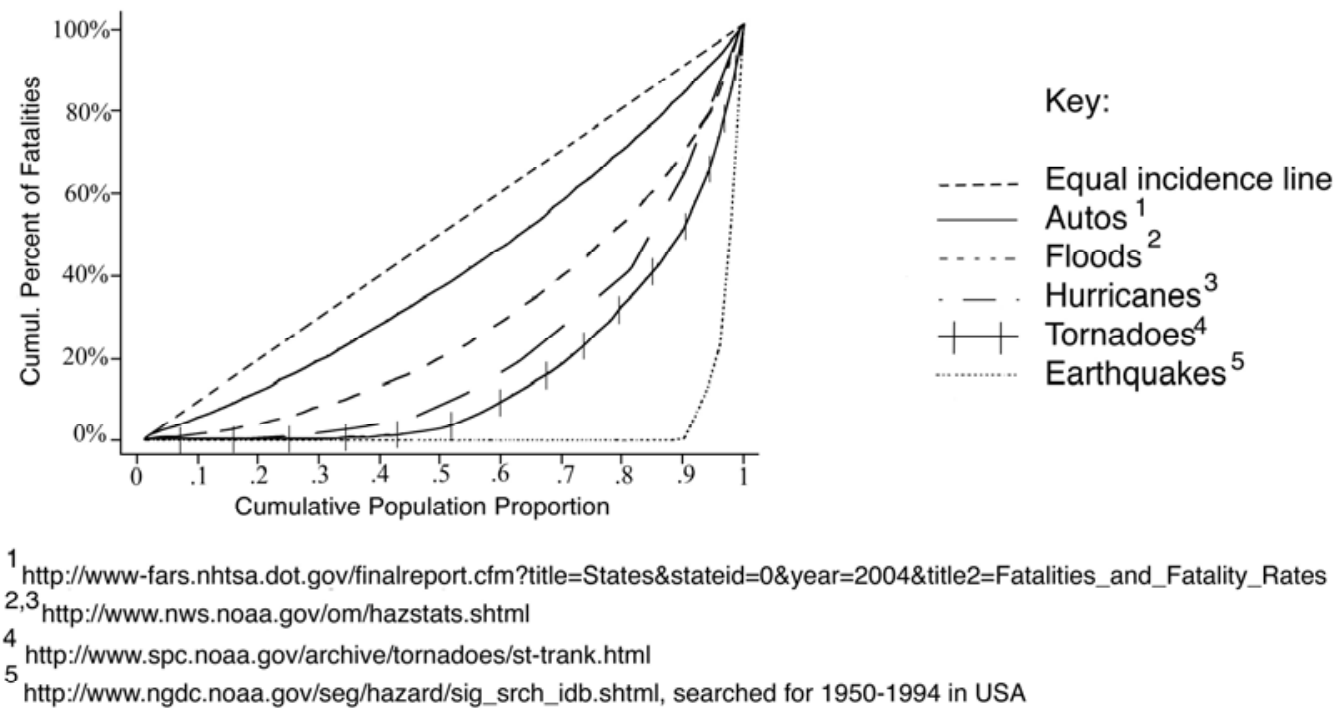

Given such skewed risk levels for natural disaster fatalities across states, we would expect individuals to update probabilities significantly, and raise their posterior risk assessments, if they had personal experience with a disaster. (The updating would be more intense if we computed results over smaller geographic areas.)

In short, although people with experiences with natural disasters update their risk levels, it is likely that they do not do so sufficiently, as seen in Table 2. Tversky and Kahneman (1974) refer to the tendency to update insufficiently as anchoring. Zeckhauser (1996, p. 115), specifically addressing catastrophes, notes that: "Neither humans nor society deal effectively with information, particularly probabilistic information.”

\subsection{Statistical results on risk beliefs}


To explore the determinants of beliefs about natural disaster fatality risks, we explore ordered probit results for the above-average, average, and below-average risk categories. We report regressions based on the Knowledge Networks sampling weights, but the results are almost identical to the unweighted results because the sample closely mirrors the U.S. population. The ordered probit coefficients have been transformed to reflect the marginal influence of each variable.

Table 4 reports five sets of regression estimates; the differences arise because different sets of region variables and disaster experience variables are included. The continuous variables included in all equations are Age (in years) and Years of education. The remaining variables in one or more equations are all 0-1 dummy variables for Female; Black, non-Hispanic; Other/multiple race, non-Hispanic; Hispanic, all races; Mid-Atlantic region, East-North-Central region, West-North Central region, South Atlantic region, East-South Central region, West-South Central region, Mountain region, Pacific region, Metropolitan residence, Household income (in tens of thousands of dollars); Household income, top category; Republican, Current smoker, Experienced natural disaster, Experienced hurricane, Experienced flood, Experienced earthquake, Experienced tornado, Hurricane state, and Hurricane state interacted with Experienced hurricane. The excluded categories in the regressions are male, white/non-Hispanic, and New England.

The equations we examined appear in their respective columns. Equation 1 includes the full set of demographic variables and whether the respondent has experienced a natural disaster. Quite reasonably, people in the high-tornado-risk states in the West-North Central region, the high-hurricane-risk states of the South Atlantic, East- 
South Central, and West-South Central regions, and the high-earthquake-risk states of the Pacific region perceive themselves as being at greater risk of suffering from these particular disasters. ${ }^{12}$ Better-educated people rate their risks as being lower, which may reflect their understanding that risk is skewed, but this is a matter worthy of further study. Republicans also assess risks as being lower. The lower risk beliefs held by welleducated and Republican respondents suggests that they may have less of a personal stake in disaster relief efforts. There is suggestive evidence about this below. As expected, having experienced a natural disaster has a powerful positive effect on risk beliefs.

Equation 2 distinguishes the effect of natural disaster experiences by the particular type of disaster. The combined disaster experience variable in equation 1 had a significant positive effect on risk beliefs for natural disasters in general. Looking at the risks individually, experiencing a tornado or a hurricane boosts risk beliefs, but experiencing a flood or an earthquake is not influential. ${ }^{13}$ These multivariate results consequently mirror the mean patterns in Table 2.

Equations 3-5 include variables indicating whether the respondent lives in a hurricane state, and an interaction of hurricane state residence with hurricane experience. They omit the regional variables that may substantially capture the influence of the hurricane state variable. The results are quite consistent across these three specifications. One effect is consistently strong and significant, namely the interactive influence of hurricane state and having experienced a hurricane. Due to the strong interrelationship of

\footnotetext{
${ }^{12}$ The listing of the states corresponding to these categories appears in the Appendix. New England is the excluded regional category.

${ }^{13}$ Looking at Figure 1, the flood result is not too surprising, since it is the least skewed of the four natural disasters. Earthquakes are the most skewed of our risks. However, a recent experience has two counterbalancing effects. It updates and raises the long-term risk level. But it lowers the immediate risk, since pressure has been released in the fault.
} 
these variables, it may be that they are influential individually, but the most powerful effect is accounted for by the interaction, perhaps because one's own experience is reinforced by learning of experiences with other hurricanes striking nearby.

The final survey results that form the basis of the estimates reported thus far were estimated using a sample from mid-April 2006. However, we have an additional sample of 115 pre-test respondents, queried just before a series of fatal tornadoes hit the Southeast in early April 2006. Given the power of the Availability Heuristic and Bayesian learning, one would expect that the effect of the variable for having experienced a tornado would be greater for the sample polled after the tornadoes than before. In ordered probit regressions, not reported, we included an interaction between the tornado experience variable and whether the sample was polled after the tornado. There was a marked upward shift in the tornado experience coefficient in the post-tornadoes sample. ${ }^{14}$

People will likely do a worse job estimating their risks from terrorism than from natural disasters. People in different regions presumably are also less able to distinguish differences in risk, because of the dearth and imprecision of knowledge about the distribution of terrorism risk. To be sure, major cities appear to be prominent terrorism targets, which may sufficiently skew risks so that everyone else is at below-average risk. But are residents of Colorado at greater or lower risk of a terrorism attack than residents of Georgia?

The ordered probit estimates reported in Table 5 show that respondents' risk beliefs are diffuse for terrorism risks. Few of the demographic variables are statistically significant, though older respondents view themselves as at lower risk, and non-Hispanic

\footnotetext{
${ }^{14}$ More specifically, the interaction variable had a coefficient of 0.468 with a standard error of 0.234 , while the experienced tornado variable remained statistically insignificant.
} 
blacks view themselves as at higher risk. Residence in a metropolitan area has a powerful positive influence, consistent with the past pattern of terrorism attacks in the United States and abroad. This result is also reminiscent of the finding by Fischhoff et al. (2003) that proximity to the World Trade Center increases terrorism risk beliefs since terror risk judgments often involve people imagining a repetition of the 9/11 experience. The effect of living in a metropolitan area is equivalent in magnitude to the effect of being a frequent flyer, namely taking more than 6 plane trips per year. ${ }^{15}$

The risk belief results for both natural hazards and terrorism risks in most respects are quite sensible in direction, but insufficient in magnitude. People who live in highly vulnerable areas should assess greater risks, and they do. People who have experienced natural disasters should assess greater risks, as they do with hurricanes and tornadoes, though not floods. Nevertheless, the level at which they assess this risk is well below what our Bayesian calculations indicate is reasonable. ${ }^{16}$ And the much more frequent and geographically concentrated natural hazards should exhibit more interpersonal differences than terrorism risks, which are not even well understood by government officials charged with the task of preventing terrorism attacks. And that is what we find.

\section{Attitudes Toward Government Disaster Relief}

After major disasters strike, there is invariably a major infusion of both private and government relief assistance. Some of this assistance is funded in advance through

\footnotetext{
${ }^{15}$ This variable is significant at the $10 \%$ level, two-sided, or $5 \%$ level one-sided test level. On a theoretical basis one would hypothesize that more plane trips should boost the risk, making a one-sided test appropriate.

${ }^{16}$ Even if everyone understood risk skewness, and was focusing on average as opposed to median, virtually all of those without personal experience should rate themselves below average.
} 
contributions to subsidized flood insurance. There is also considerable post-disaster aid for which there are no charges paid either ex ante or ex post.

We distinguish three different possible motivations for governmental relief efforts. First, public support for aid may be governed by individual self-interest. To the extent that people believe that they too will be at elevated risk for catastrophic losses, they will support disaster aid to establish a precedent. Second, people may be motivated by pure compassion. Irrespective of why people have suffered the damages from disasters, they may support assistance that will help restore the victims' welfare to or toward their pre-disaster levels. Third, support for relief efforts may stem from what we term “efficient compassion.” Efficient compassion supports relief efforts but is less willing to provide aid if the damage arose because of problems of moral hazard or a failure by disaster victims to take advantage of the protections already offered by the market. For example, people who knowingly choose to live in identified high-risk areas, and insurance companies that fail to take avail themselves of appropriate reinsurance opportunities, will be deemed less deserving of assistance.

To explore these different sources of support for government relief policies, we examined several natural disaster and terrorism contexts. The three natural disaster aid scenarios involved recovery efforts generally, assistance to those who live in high-risk areas, and assistance to people who return to New Orleans after Hurricane Katrina and rebuild in high-risk areas. The survey text for these three questions was as follows:

The U.S. government subsidizes insurance programs to cover property losses from natural disasters, and the U.S. government often provides money to help in the recovery efforts. Do you believe the U.S. government should provide subsidized insurance and compensation to victims of natural disasters such as hurricanes, floods, tornados, and earthquakes? 
In some cases people who are victims of natural disasters have purposely chosen to live in a risky area. Often, these are attractive and expensive locations, such as along a beach or next to a river. Do you believe that the U.S. government should provide subsidized insurance and compensation to victims of natural disasters who chose to live in high-risk areas?

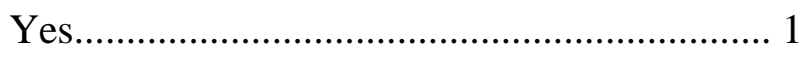

No

After disasters such as Hurricane Katrina, people rebuild houses that have been destroyed. In some cases these houses are rebuilt in high-risk areas, such as the low lying areas of New Orleans that will be vulnerable to future flooding. If people do rebuild in areas the U.S. government indicates are high-risk, do you believe the U.S. government should provide compensation if a major hurricane strikes New Orleans again?

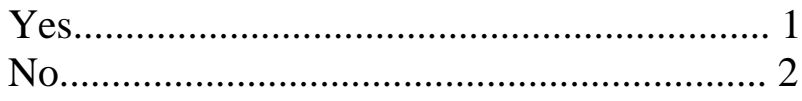

The first disaster relief question pertains to general support for disaster insurance and compensation after the major types of natural disasters. This question raised no explicit concerns regarding moral hazard or inefficient self-insurance or self-protective behavior. For the entire sample, 82.2 percent supported such assistance.

The second disaster relief question raises the issue of people choosing to live in a risky area that exposed them to a greater level of risk. Given the voluntary nature of such risk taking, those exhibiting efficient compassion should be less willing to provide relief in this situation. That prediction is borne out, as only 37.0 percent favor relief in this situation, as compared to 82.2 percent in the initial case.

The third question addresses a specific type of moral hazard situation that pertains specifically to the rebuilding efforts in New Orleans. Unlike the previous question, 
which highlighted the possibility of providing aid to perhaps less sympathetic owners of expensive beachfront homes, this question pertains to homeowners attempting to rebuild their homes in the high-risk areas of New Orleans after Hurricane Katrina, who are for the most part poor and have lost a lot. Compassion would suggest that aid is merited, but such a decision would bear a strong component of inefficiency. Only a minority of respondents—36.1 percent—were willing to support assistance to people suffering losses in high-risk New Orleans areas following the rebuilding efforts.

To explore how personal self-interest influences these different levels of support, the three panels in Table 6 summarize the support for each policy by those at the three different levels of personally assessed risk of death from natural disasters. The degree of support rises as one moves across the columns from the below-average risk group to the average risk group and then to the above-average risk group, showing that self-interest does play a role. The differences across the different risk perception categories are statistically significant in all three instances, with Wilcoxen rank sum test values of $\mathrm{z}=$ 2.082 for victims in general, 4.490 for victims exposed to high voluntary risks, and 2.205 for victims of the next New Orleans hurricane. While the expected pattern is borne out, the extent of the increased support for relief from moving from the below-average risk group to the above-average risk group is only 5.3 percent for aid to New Orleans and 6.9 percent for relief when there is no explicit moral hazard issue. The moral hazard question exhibits the greatest influence of personal risk levels; there is a 19.7 percent upswing in the level of support across risk levels. Apparently moral hazard is not as much of a concern if individuals have a strong self-interest in maintaining relief efforts that will be of benefit to them. 
To explore what personal characteristics determine the levels of support for relief efforts, Table 7 reports a series of probit regressions on the probability of support, where the coefficients have been transformed to reflect marginal probabilities. The first two regression columns are for the first two relief questions and the third column is for aid to New Orleans after the next hurricane.

Many of the significant effects show a consistent pattern across all three relief questions. Older respondents are less willing to support relief efforts for victims living in high-risk areas or in New Orleans after the next hurricane, even after controlling for household income and other background characteristics. However, age imposes no such reluctance for the initial disaster risk question. It is only when people are knowingly behaving in an inefficient manner that older respondents decrease their levels of support in equations 2 and 3.

Groups that are generally more liberal politically, namely female and nonHispanic black respondents, are more supportive of assistance. Women have a greater likelihood of being willing to support government relief efforts generally, but not when there is inefficient behavior in equations 2 and 3 . Black respondents have a greater willingness to support general relief than does the omitted category of white respondents. Interestingly, non-Hispanic black respondents are much more likely to support relief in all cases, even when people live in high-risk areas, as in equations 2 and 3 of Table 7. As the New Orleans experience indicates, the residents of many of these high-risk areas tend to be poor and, in the case of New Orleans, predominantly black. The greater affordability of homes in areas where land values are low because of the greater risk tends to produce racial differences. Black non-Hispanic survey respondents— 
presumably sensitive to such causality and the horrific New Orleans experience-are much more willing to support government relief efforts to continue support even though the victim has chosen to live in a risky locale.

The regional characteristic variables are not as influential in the aid equations as in the earlier risk belief equations. Perhaps the impetus for relief does not vary greatly across the United States. However, people who live in high-risk areas seem to have greater tolerance for moral hazard in equation 2, as exemplified by the positive effects of residing in the Pacific and West-South Central regions.

No such regional variations are observed for equation 3 representing aid to New Orleans. None of the broad regional groups is statistically significant at the usual levels. In probit regressions not reported, we omit these broad regional categories and explore whether living in a hurricane state or being a resident of Louisiana or Mississippi boosted the levels of support for aid to New Orleans after the next hurricane. Neither of these variables is statistically significant.

Political orientation is a main driver of the support for relief, not just for the efficient compassion questions, but for all the relief options. In every instance, Republicans have a consistently lower probability of supporting the relief policies than do Democrats and independents. After controlling for political affiliation, blacks have higher probabilities for support; females also have higher probabilities, though not where moral hazard is a prime factor. Presumably, these groups are more liberal than their mere political affiliation indicates.

The equations also included a measure of individual risk-taking behavior- the general health risk exposure of the respondent as reflected in whether they currently 
smoke cigarettes. Smokers face a considerable smoking-related mortality risk; their probability of premature death due to smoking is $1 / 6$ to $1 / 3$. The smoker variable consequently captures willingness to expose oneself to extremely large health risks. Beyond this, the smoker variable may also reflect a tolerance for others who take risks and are guilty of moral hazard, since smokers are frequent targets of criticism for their own risk-taking behavior. For the two relief questions involving individual choices to engage in risky behavior, smokers are more forgiving of decisions involving moral hazard and are more willing to support relief. Both effects are significant at the 10 percent level. However, for Equation (1) in which moral hazard plays a minor role, there is no significant smoker effect.

Respondents who believe that they face a below-average disaster fatality risk. This group is significantly less supportive of relief efforts except in Equation (1), which pertains to the situation of efficient compassion. The moral hazard scenarios generate the greatest negative differential support for relief among those who perceive their own natural disaster risk to be below average.

The terrorism component of the survey included similar questions regarding government relief. The survey included the possibility of relief aid to victims of terrorism. It also inquired about relief for insurance companies, which one would expect to be much less sympathetic recipients of assistance, hence to get lower levels of support. The specific questions were as follows:

After the 9/11 terrorist attack on the World Trade Center the U.S. government provided compensation to the families of the terrorism victims to make up for the income losses their families experienced. Do you believe that in the future the government should provide such compensation to U.S. victims of international terrorists? 
Insurance companies also suffer losses after major terrorism attacks such as 9/11. Should the U.S. government provide insurance coverage to insurance companies to reduce the financial risks companies might face from major terrorist attacks?

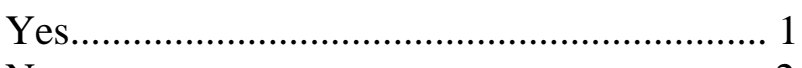

No................................................................. 2

A substantial majority, 77.1 percent of respondents, favor aid to terrorism victims. A surprisingly high 52.1 percent favor aid to insurance companies, presumably indicating some comprehension of market function, for example, that such relief would predominantly flow through to insureds. ${ }^{17}$

Table 8 distinguishes the level of support for these two types of government assistance as a function of the individual's perceived personal risk of death from terrorism. Based on the Wilcoxen rank sum tests, the willingness to support terrorism victims $(z=3.649)$ or insurance companies $(z=2.590)$ differs significantly across the different risk belief categories, though without consistent patterns of influence. The first set of results for aiding victims displays no consistent pattern, whereas one would have expected the levels of support to rise as subjective risk rises. The support for aid to insurance companies is more responsive to individual risk beliefs, increasing from 48.6 percent for the below-average risk category to 62.8 percent for the above-average risk category.

As with the regression results for terrorism risk beliefs, the probit regressions for the two terrorism-aid questions reported in Table 9 show far fewer significant effects than the natural hazard regressions. This difference arises in part because unlike natural

\footnotetext{
${ }^{17}$ To determine how much of aid to insurance companies would translate to lower rates, or the ability to make payouts given a catastrophic incident, would be a difficult calculation even for economists.
} 
hazards, which are geographically concentrated in well-known areas, terrorism risks are poorly understood. Indeed, none of the regional dummy variables is statistically significant. Perhaps more importantly, people may feel that whereas people can choose to live in areas not threatened by natural disasters, terrorism risks are beyond their control, and are at least partly the responsibility of a government that failed to protect them.

Several of the personal characteristic variables display patterns that mirror the natural hazard results. Older respondents are less willing to support either type of postterrorism relief. Non-Hispanic blacks and woman are more supportive of aiding terrorism victims after an attack, but only women would aid insurance companies. Better-educated respondents are less supportive of post-terrorist attack aid.

The negative effect of the Republican variable parallels the natural disaster results. Republicans are less supportive of aid to terrorism victims, with a coefficient that is large absolutely, and both negative and significant. They are relatively less stingy with insurance companies: their insurance company coefficient, though also negative, is only one-third the value of that for victims, and statistically insignificant. Given traditional understandings about political attitudes, and beliefs or skepticism about trickle down processes, it is not surprising that blacks are much less likely to help insurance companies, whereas Republicans are less likely to help victims directly.

Of the various personal risk variables, the Current smoker variable is of greatest interest. Smoking is by far the riskiest personal consumption activity that people engage in on a large scale. This variable consequently provides an excellent measure of overall attitudes toward risk-taking behavior. The Current smoker variable has an effect that 
accords with prior findings about risk takers. Smokers are more supportive of aiding victims of terrorism, just as they were often more supportive of aiding natural disaster victims. Frequent flyers who take more than 6 plane trips per year are not more supportive of relief, and the personal fatality risk assessments display the same inconsistent pattern as the cross tabulations in Table 8.

\section{Conclusion}

This paper explored two broad questions: 1. What factors drive individuals' beliefs about their risks from various disasters, and how accurate are those beliefs? 2. What policies do individuals favor for disaster relief, and how do those policies relate to their assessed risks?

The answer to the first question is that risk beliefs have many rational components, but fall short of what one would expect with fully rational Bayesian assessments of risk. Personal experience and location-related risk influence risk assessments in the right direction, but insufficiently. These factors should have a very powerful influence, as our Lorenz Curve for fatality risks by state shows that natural disaster risks are highly concentrated, unlike auto fatality risks.

For each of our four natural disasters, more than half of our respondents thought that their fatality risk from natural disasters was below average, and another roughly thirty-five percent thought their risk was average. Even people who had experienced disasters did not differ markedly from those who had not.

A common explanation for apparent underestimation of risks, such as those from auto accidents, is that individuals suffer from an illusion of control. That explanation 
does not apply to natural disasters. A plausible hypothesis, worthy of further study, is that individuals actually understand the skewness in the distribution of risk. Though only half of the population can be below median risk, the vast majority are below average in risk. That is surely true for auto accidents as well, the favorite domain for "control" hypotheses.

More than four-fifths of our respondents favored government assistance for victims of natural disasters, but this fraction fell to only one-third when the natural disasters happened to people living in high-risk areas. This decline suggests that respondents intuitively understand the concept of moral hazard. We label this phenomenon "efficient compassion." That is, there is a strong element of compassion in their responses, but it is tempered when disaster victims have knowingly exposed themselves to high risk. Individuals who perceive themselves to be at greater personal risk are more supportive of government assistance, as are groups that tend to be liberal politically. Black respondents, who may have been particularly struck by the governmental failure to rescue the black population of New Orleans from Hurricane Katrina, are much more supportive of continued aid to that city. In short, policy preferences for disaster relief reflect both compassion for the unfortunate, and a dollop of self-interest. 


\section{References}

Born, Patricia and W. Kip Viscusi. (2006). "The Catastrophic Effects of Natural Disasters on Insurance Markets.” Journal of Risk and Uncertainty 33 (1/2).

Camerer, Colin, and Howard Kunreuther. (1989). "Decision Processes for Low Probability Events: Policy Implications.” Journal of Policy Analysis and Management 8 (4): 565-92.

Fischhoff, Baruch, et al. (1981). Acceptable Risk. Cambridge: Cambridge University Press.

Fischhoff, Baruch, et al. (2003). "Judged Terror Risk and Proximity to the World Trade Center.” Journal of Risk and Uncertainty 26: 137-151.

Kunreuther, Howard, and Mark Pauly (2004). "Why Don’t People Insure Against Large Losses?” Journal of Risk and Uncertainty 28: 5-21.

Lichtenstein, Sara, Paul Slovic, Baruch Fischhoff, Mark Layman, and Barbara Combs. (1978). “Judged Frequency of Lethal Events.” Journal of Experimental Psychology: Human Learning and Memory 4:551-78.

Raiffa, Howard. (1997). Decision Analysis. New York: McGraw-Hill College.

Rethans, Arno J. (1979). An Investigation of Consumer Perceptions of Product Hazards. Doctoral Dissertation, University of Oregon-Eugene.

Revkin, Andrew C. (2006). “Climate Experts Warn of More Coastal Building,” New York Times, 25 July. Available at www.nytimes.com/2006/07/25/science/earth/ 25coast.html?_r=1\&oref=slogin.

Tversky, Amos, and Daniel Kahneman. (1974). “Judgment under Uncertainty: Heuristics and Biases.” Science 185: 1124-1131.

Viscusi, W. Kip. (2002). Smoke-Filled Rooms: A Postmortem on the Tobacco Deal. Chicago: University of Chicago Press.

Viscusi, W. Kip, and Wesley Magat. (1987.) Learning about Risk: Consumer and Worker Responses to Hazard Information. Cambridge: Harvard University Press.

Viscusi, W. Kip, and Richard Zeckhauser. (2003). "Sacrificing Civil Liberties to Reduce Terrorism Risks.” Journal of Risk and Uncertainty 26: 99-120.

Weinstein, Neil D., and William M. Klein. (1996). "Unrealistic Optimism: Present and Future.” Journal of Social and Clinical Psychology 15: 1-8. 
Zeckhauser, Richard, “The Economics of Catastrophes.” Journal of Risk and Uncertainty 12, 1996, 113-140. 
Table 1. Subjective Level of Risk by Type of Fatality

\begin{tabular}{lrrrrrr}
\hline & \multicolumn{2}{c}{$\begin{array}{c}\text { Auto } \\
\text { fatality risk }\end{array}$} & \multicolumn{2}{c}{$\begin{array}{c}\text { Natural disaster } \\
\text { fatality risk }\end{array}$} & \multicolumn{2}{c}{$\begin{array}{c}\text { Terrorism } \\
\text { fatality risk }\end{array}$} \\
Subjective level of risk & Number & Percent & Number & Percent & Number & Percent \\
\hline Below-average fatality risk & 473 & 43.9 & 631 & 58.6 & 545 & 50.6 \\
Average fatality risk & 513 & 47.6 & 376 & 34.9 & 446 & 41.4 \\
Above-average fatality risk & 91 & 8.5 & 70 & 6.5 & 86 & 8.0 \\
Observations & 1,077 & 100.0 & 1,077 & 100.0 & 1,077 & 100.0 \\
\hline
\end{tabular}


Table 2. Subjective Level of Natural Disaster Fatality Risk With and Without Experience with the Disaster

\begin{tabular}{|c|c|c|c|c|}
\hline \multirow{3}{*}{$\begin{array}{l}\text { Subjective level of natural disaster } \\
\text { fatality risk }\end{array}$} & \multicolumn{4}{|c|}{ Experienced hurricane } \\
\hline & \multicolumn{2}{|c|}{ No } & \multicolumn{2}{|c|}{ Yes } \\
\hline & Number & Percent & Number & Percent \\
\hline Below-average fatality risk & 487 & 61.3 & 144 & 50.9 \\
\hline Average fatality risk & 267 & 33.6 & 109 & 38.5 \\
\hline Above-average fatality risk & 40 & 5.0 & 30 & 10.6 \\
\hline \multirow[t]{4}{*}{ Observations } & 794 & 100.0 & 283 & 100.0 \\
\hline & \multicolumn{4}{|c|}{ Experienced flood } \\
\hline & \multicolumn{2}{|c|}{ No } & \multicolumn{2}{|c|}{ Yes } \\
\hline & Number & Percent & Number & Percent \\
\hline Below-average fatality risk & 470 & 59.1 & 161 & 57.1 \\
\hline Average fatality risk & 279 & 35.1 & 97 & 34.4 \\
\hline Above-average fatality risk & 46 & 5.8 & 24 & 8.5 \\
\hline \multirow[t]{4}{*}{ Observations } & 795 & 100.0 & 282 & 100.0 \\
\hline & \multicolumn{4}{|c|}{ Experienced earthquake } \\
\hline & \multicolumn{2}{|c|}{ No } & \multicolumn{2}{|c|}{ Yes } \\
\hline & Number & Percent & Number & Percent \\
\hline Below-average fatality risk & 466 & 59.0 & 165 & 57.5 \\
\hline Average fatality risk & 278 & 35.2 & 98 & 34.1 \\
\hline Above-average fatality risk & 46 & 5.8 & 24 & 8.4 \\
\hline \multirow[t]{4}{*}{ Observations } & 790 & 100.0 & 287 & 100.0 \\
\hline & \multicolumn{4}{|c|}{ Experienced tornado } \\
\hline & \multicolumn{2}{|c|}{ No } & \multicolumn{2}{|c|}{ Yes } \\
\hline & Number & Percent & Number & Percent \\
\hline Below-average fatality risk & 465 & 61.5 & 166 & 51.7 \\
\hline Average fatality risk & 246 & 32.5 & 130 & 40.5 \\
\hline Above-average fatality risk & 45 & 6.0 & 25 & 7.8 \\
\hline Observations & 756 & 100.0 & 321 & 100.0 \\
\hline
\end{tabular}




\section{Table 3. Subjective Level of Natural Disaster Fatality Risk for Hurricane and Not-Hurricane States ${ }^{a}$}

\begin{tabular}{lccccc}
\hline $\begin{array}{l}\text { Subjective level of natural } \\
\text { disaster fatality risk }\end{array}$ & \multicolumn{2}{c}{ Hurricane state } & & \multicolumn{2}{c}{ Not-hurricane state } \\
\cline { 5 - 6 } & Number & Percent & & Number & Percent \\
\hline Below-average fatality risk & 55 & 37.9 & 576 & 61.8 \\
Average fatality risk & 67 & 46.2 & 309 & 33.2 \\
Above-average fatality risk & 23 & 15.9 & 47 & 5.0 \\
Observations & 145 & 100.0 & 932 & 100.0 \\
\hline
\end{tabular}

${ }^{\mathrm{a}}$ Hurricane states are Florida, Louisiana, Mississippi, and Texas. 
Table 4. Ordered Probit Regressions for

Subjective Natural Disaster Fatality Risk ${ }^{\text {a }}$

\begin{tabular}{|c|c|c|c|c|c|}
\hline Independent Variables & (1) & (2) & (3) & (4) & (5) \\
\hline \multirow[t]{2}{*}{ Age } & 0.001 & 0.0004 & 0.0004 & 0.001 & -0.0003 \\
\hline & $(0.003)$ & $(0.003)$ & $(0.003)$ & $(0.003)$ & $(0.003)$ \\
\hline \multirow[t]{2}{*}{ Female } & -0.065 & -0.066 & -0.063 & -0.072 & -0.053 \\
\hline & $(0.091)$ & $(0.091)$ & $(0.091)$ & $(0.091)$ & $(0.092)$ \\
\hline \multirow[t]{2}{*}{ Black, non-Hispanic } & -0.089 & -0.085 & -0.084 & -0.061 & -0.027 \\
\hline & $(0.142)$ & $(0.141)$ & $(0.142)$ & $(0.142)$ & $(0.143)$ \\
\hline \multirow{2}{*}{$\begin{array}{l}\text { Other/multiple race, } \\
\text { non-Hispanic }\end{array}$} & -0.138 & -0.139 & -0.161 & -0.163 & -0.111 \\
\hline & $(0.250)$ & $(0.255)$ & $(0.257)$ & $(0.261)$ & $(0.273)$ \\
\hline \multirow[t]{2}{*}{ Hispanic, all races } & -0.130 & -0.113 & -0.152 & -0.150 & -0.166 \\
\hline & $(0.167)$ & $(0.165)$ & $(0.164)$ & $(0.163)$ & $(0.156)$ \\
\hline \multirow{2}{*}{ Mid-Atlantic } & 0.170 & 0.181 & 0.170 & 0.130 & \\
\hline & $(0.242)$ & $(0.246)$ & $(0.247)$ & $(0.249)$ & \\
\hline \multirow[t]{2}{*}{ East-North Central } & 0.321 & 0.304 & 0.283 & 0.223 & \\
\hline & $(0.237)$ & $(0.241)$ & $(0.242)$ & $(0.244)$ & \\
\hline \multirow[t]{2}{*}{ West-North Central } & $0.606^{*}$ & $0.600^{*}$ & $0.569 *$ & $0.516+$ & \\
\hline & $(0.265)$ & $(0.273)$ & $(0.275)$ & $(0.279)$ & \\
\hline \multirow[t]{2}{*}{ South Atlantic } & $0.781 * *$ & $0.730 * *$ & $0.644^{* *}$ & $0.601 *$ & \\
\hline & $(0.228)$ & $(0.231)$ & $(0.241)$ & $(0.243)$ & \\
\hline \multirow[t]{2}{*}{ East-South Central } & $0.613^{*}$ & $0.583 *$ & $0.524 *$ & $0.492+$ & \\
\hline & $(0.240)$ & $(0.248)$ & $(0.251)$ & $(0.253)$ & \\
\hline \multirow[t]{2}{*}{ West-South Central } & $0.663^{* *}$ & $0.646^{* *}$ & 0.434 & $0.499+$ & \\
\hline & $(0.244)$ & $(0.248)$ & $(0.293)$ & $(0.290)$ & \\
\hline \multirow[t]{2}{*}{ Mountain } & -0.067 & -0.095 & -0.105 & -0.165 & \\
\hline & $(0.281)$ & $(0.276)$ & $(0.276)$ & $(0.277)$ & \\
\hline \multirow[t]{2}{*}{ Pacific } & $0.641 * *$ & $0.668 *$ & $0.663^{*}$ & $0.597 *$ & \\
\hline & $(0.232)$ & $(0.260)$ & $(0.259)$ & $(0.262)$ & \\
\hline \multirow{2}{*}{ Metropolitan residence } & $0.210+$ & 0.197 & 0.169 & 0.170 & 0.093 \\
\hline & $(0.125)$ & $(0.124)$ & $(0.127)$ & $(0.127)$ & $(0.128)$ \\
\hline \multirow[t]{2}{*}{ Years of education } & $-0.042 *$ & $-0.045^{*}$ & $-0.044^{*}$ & $-0.039+$ & $-0.038+$ \\
\hline & $(0.020)$ & $(0.020)$ & $(0.020)$ & $(0.020)$ & $(0.020)$ \\
\hline \multirow[t]{2}{*}{ Household income } & -0.009 & -0.008 & -0.007 & -0.009 & -0.010 \\
\hline & $(0.015)$ & $(0.015)$ & $(0.015)$ & $(0.015)$ & $(0.015)$ \\
\hline \multirow{2}{*}{$\begin{array}{l}\text { Household income, } \\
\text { top category }\end{array}$} & -0.421 & -0.507 & -0.538 & -0.476 & -0.465 \\
\hline & $(0.484)$ & $(0.487)$ & $(0.477)$ & $(0.461)$ & $(0.468)$ \\
\hline \multirow[t]{2}{*}{ Republican } & $-0.188+$ & $-0.189+$ & $-0.198 *$ & $-0.188+$ & $-0.177+$ \\
\hline & $(0.097)$ & $(0.097)$ & $(0.098)$ & $(0.098)$ & $(0.097)$ \\
\hline \multirow[t]{2}{*}{ Current smoker } & 0.122 & 0.106 & 0.113 & 0.117 & 0.109 \\
\hline & $(0.112)$ & $(0.113)$ & $(0.113)$ & $(0.113)$ & $(0.111)$ \\
\hline
\end{tabular}


Experienced natural disaster

Experienced hurricane

(0.102)

Experienced flood

$0.215^{*}$

0.168

(0.108)

(0.112)

0.046

0.081

0.032

0.034

(0.129)

(0.123)

(0.107)

(0.107)

0.031

0.0001

Experienced earthquake

0.145

0.140

(0.107)

(0.108)

(0.136)

(0.135)

0.154

0.230 *

Experienced tornado

0.248 *

$0.255^{*}$

(0.136)

(0.109)

(0.103)

(0.103)

0.279

0.250 *

$0.257 * *$

Hurricane state

(0.175)

(0.103)

(0.099)

Hurricane state $\mathrm{x}$ experienced

$-0.138$

0.050

Hurricane

$(0.241)$

(0.187)

Observations

1077

1077

$0.656^{*}$

(0.264)

(0.255)

1077

${ }^{a}$ Coefficient estimates (and standard errors in parentheses) from ordered probits on dependent variable, subjective natural disaster fatality risk, which varies from 1 (below-average risk), to 2 (average risk), to 3 (above-average risk). Regressions adjust for sample weights.

+ significant at 10\% level, * significant at 5\% level, ** significant at 1\% level; two-tailed test. 
Table 5. Ordered Probit Regressions on Subjective Terrorism Fatality Risk ${ }^{\mathrm{a}}$

\begin{tabular}{lc}
\hline \multicolumn{1}{c}{ Independent Variables } & $\begin{array}{c}\text { Coefficient } \\
\text { (asymptotic std. error) }\end{array}$ \\
\hline Age & $-0.005^{*}$ \\
& $(0.003)$ \\
Female & 0.138 \\
& $(0.088)$ \\
Black, non-Hispanic & $0.389^{* *}$ \\
Other/multiple race, non-Hispanic & $(0.139)$ \\
& 0.007 \\
Hispanic, all races & $(0.243)$ \\
Mid-Atlantic & -0.018 \\
& $(0.142)$ \\
East-North Central & 0.230 \\
& $(0.233)$ \\
West-North Central & -0.229 \\
& $(0.233)$ \\
South Atlantic & 0.023 \\
& $(0.253)$ \\
East-South Central & 0.330 \\
& $(0.230)$ \\
West-South Central & -0.023 \\
& $(0.276)$ \\
Mountain & 0.242 \\
& $(0.242)$ \\
Pacific & 0.084 \\
& $(0.255)$ \\
Metropolitan residence & 0.034 \\
Years of education & $(0.228)$ \\
& $0.508^{* *}$ \\
Household income & $(0.118)$ \\
Household income, top category & -0.001 \\
& $(0.020)$ \\
& -0.004 \\
& $0.014)$ \\
& 0.206 \\
& $(0.360)$ \\
& \\
& \\
&
\end{tabular}


Republican

$-0.020$

Current smoker

More than 6 plane trips per year

Observations
(0.093)

$-0.102$

(0.106)

$0.545+$

(0.296)

${ }^{\text {a }}$ Coefficient estimates (asymptotic standard errors in parentheses) from ordered probits on dependent variable, subjective terrorism fatality risk, which varies from 1 (belowaverage risk), to 2 (average risk), to 3 (above-average risk). Regressions adjust for sample weights.

+ significant at $10 \%$ level, * significant at $5 \%$ level, ${ }^{* *}$ significant at $1 \%$ level; two-tailed test. 
Table 6. Preferences for Government Assistance by Subjective Level of Natural Disaster Fatality Risk

\section{Assist victims of natural disasters}

Subjective level of natural disaster fatality risk

\begin{tabular}{lcccccc} 
& \multicolumn{2}{c}{$\begin{array}{c}\text { Below-average } \\
\text { fatality risk }\end{array}$} & \multicolumn{2}{c}{$\begin{array}{c}\text { Average } \\
\text { fatality risk }\end{array}$} & \multicolumn{2}{c}{$\begin{array}{c}\text { Above-average } \\
\text { fatality risk }\end{array}$} \\
& Number & Percent & Number & Percent & Number & Percent \\
\hline No & 125 & 19.8 & 58 & 15.4 & 9 & 12.9 \\
Yes & 506 & 80.2 & 318 & 84.6 & 61 & 87.1 \\
\hline
\end{tabular}

Assist victims of natural disasters living in high risk areas

Subjective level of natural disaster fatality risk

\begin{tabular}{lcccccc} 
& \multicolumn{2}{c}{$\begin{array}{c}\text { Below-average } \\
\text { fatality risk }\end{array}$} & \multicolumn{2}{c}{$\begin{array}{c}\text { Average } \\
\text { fatality risk }\end{array}$} & \multicolumn{2}{c}{$\begin{array}{c}\text { Above-average } \\
\text { fatality risk }\end{array}$} \\
& Number & Percent & Number & Percent & Number & Percent \\
\hline No & 431 & 68.3 & 213 & 56.6 & 34 & 48.6 \\
Yes & 200 & 31.7 & 163 & 43.4 & 36 & 51.4 \\
\hline
\end{tabular}

Assist victims of next New Orleans hurricane

Subjective level of natural disaster fatality risk

Below-average Average fatality risk fatality risk

Number Percent Number Percent Number Percen

\begin{tabular}{lcccccc} 
& Number & Percent & Number & Percent & Number & Percent \\
\hline No & 421 & 66.7 & 224 & 59.6 & 43 & 61.4 \\
Yes & 210 & 33.3 & 152 & 40.4 & 27 & 38.6 \\
\hline Observations & 631 & 100.0 & 376 & 100.0 & 70 & 100.0 \\
\hline
\end{tabular}


Table 7. Ordered Probit Regressions for Government Relief for Natural Disaster Losses ${ }^{\text {a }}$

\begin{tabular}{|c|c|c|c|}
\hline Independent Variables & $\begin{array}{c}\text { (1) } \\
\text { Any } \\
\text { natural } \\
\text { disaster } \\
\text { victims }\end{array}$ & $\begin{array}{c}(2) \\
\text { Victims } \\
\text { living in } \\
\text { high risk } \\
\text { areas } \\
\end{array}$ & $\begin{array}{c}(3) \\
\text { Victims in } \\
\text { New } \\
\text { Orleans } \\
\text { next time } \\
\end{array}$ \\
\hline Age & $\begin{array}{l}-0.003 \\
(0.003)\end{array}$ & $\begin{array}{c}-0.019 * * \\
(0.003)\end{array}$ & $\begin{array}{c}-0.016 * * \\
(0.003)\end{array}$ \\
\hline Female & $\begin{array}{c}0.278^{*} \\
(0.111)\end{array}$ & $\begin{array}{c}0.110 \\
(0.100)\end{array}$ & $\begin{array}{c}0.081 \\
(0.101)\end{array}$ \\
\hline Black, non-Hispanic & $\begin{array}{c}0.498 * \\
(0.232)\end{array}$ & $\begin{array}{l}0.657 * * \\
(0.159)\end{array}$ & $\begin{array}{l}0.724^{* *} \\
(0.165)\end{array}$ \\
\hline Other/multiple race, non-Hispanic & $\begin{array}{c}0.119 \\
(0.235)\end{array}$ & $\begin{array}{l}-0.447+ \\
(0.244)\end{array}$ & $\begin{array}{c}0.080 \\
(0.250)\end{array}$ \\
\hline Hispanic, all races & $\begin{array}{c}0.028 \\
(0.186)\end{array}$ & $\begin{array}{l}-0.042 \\
(0.162)\end{array}$ & $\begin{array}{c}0.215 \\
(0.160)\end{array}$ \\
\hline Mid-Atlantic & $\begin{array}{c}0.014 \\
(0.309)\end{array}$ & $\begin{array}{c}0.450 \\
(0.277)\end{array}$ & $\begin{array}{c}0.169 \\
(0.259)\end{array}$ \\
\hline East-North Central & $\begin{array}{l}-0.017 \\
(0.308)\end{array}$ & $\begin{array}{c}0.354 \\
(0.273)\end{array}$ & $\begin{array}{l}-0.051 \\
(0.257)\end{array}$ \\
\hline West-North Central & $\begin{array}{l}-0.149 \\
(0.336)\end{array}$ & $\begin{array}{l}-0.153 \\
(0.338)\end{array}$ & $\begin{array}{l}-0.290 \\
(0.316)\end{array}$ \\
\hline South Atlantic & $\begin{array}{c}0.093 \\
(0.298)\end{array}$ & $\begin{array}{c}0.239 \\
(0.270)\end{array}$ & $\begin{array}{l}-0.197 \\
(0.253)\end{array}$ \\
\hline East-South Central & $\begin{array}{l}-0.199 \\
(0.340)\end{array}$ & $\begin{array}{c}0.261 \\
(0.304)\end{array}$ & $\begin{array}{l}-0.062 \\
(0.291)\end{array}$ \\
\hline West-South Central & $\begin{array}{l}-0.067 \\
(0.316)\end{array}$ & $\begin{array}{c}0.639 * \\
(0.299)\end{array}$ & $\begin{array}{c}0.287 \\
(0.286)\end{array}$ \\
\hline Mountain & $\begin{array}{l}-0.015 \\
(0.323)\end{array}$ & $\begin{array}{c}0.589 * \\
(0.283)\end{array}$ & $\begin{array}{c}0.221 \\
(0.273)\end{array}$ \\
\hline Pacific & $\begin{array}{l}-0.032 \\
(0.300)\end{array}$ & $\begin{array}{c}0.579 * \\
(0.273)\end{array}$ & $\begin{array}{l}-0.072 \\
(0.257)\end{array}$ \\
\hline Metropolitan residence & $\begin{array}{c}0.022 \\
(0.140)\end{array}$ & $\begin{array}{c}0.025 \\
(0.137)\end{array}$ & $\begin{array}{l}-0.038 \\
(0.139)\end{array}$ \\
\hline Years of education & $\begin{array}{l}-0.058 * \\
(0.028)\end{array}$ & $\begin{array}{l}-0.001 \\
(0.023)\end{array}$ & $\begin{array}{l}-0.017 \\
(0.024)\end{array}$ \\
\hline Household income & $\begin{array}{c}0.005 \\
(0.018)\end{array}$ & $\begin{array}{c}0.009 \\
(0.016)\end{array}$ & $\begin{array}{c}0.0001 \\
(0.016)\end{array}$ \\
\hline Household income, top category & $\begin{array}{l}-0.338 \\
(0.409)\end{array}$ & $\begin{array}{l}-0.043 \\
(0.401)\end{array}$ & $\begin{array}{c}0.286 \\
(0.377)\end{array}$ \\
\hline Republican & $\begin{array}{c}-0.687 * * \\
(0.114)\end{array}$ & $\begin{array}{l}-0.385^{* *} \\
(0.104)\end{array}$ & $\begin{array}{c}-0.577^{* *} \\
(0.105)\end{array}$ \\
\hline Current smoker & 0.145 & $0.207+$ & $0.189+$ \\
\hline
\end{tabular}




\begin{tabular}{llll} 
& $(0.132)$ & $(0.114)$ & $(0.115)$ \\
Experienced natural disaster & $-0.237^{*}$ & 0.018 & -0.024 \\
& $(0.117)$ & $(0.108)$ & $(0.108)$ \\
Above-average disaster fatality risk & -0.124 & 0.162 & -0.161 \\
& $(0.230)$ & $(0.211)$ & $(0.207)$ \\
Below-average disaster fatality risk & -0.191 & $-0.338^{* *}$ & $-0.264^{*}$ \\
& $(0.123)$ & $(0.108)$ & $(0.109)$ \\
& & & \\
Constant & & & \\
Observations & $2.322^{* *}$ & 0.284 & $0.848^{*}$ \\
\hline
\end{tabular}

${ }^{a}$ Coefficient estimates (and standard errors in parentheses) from probit regressions on indicator variables, where 1 indicates individual chose "yes" in answer to the aid question. Excluded categories in regressions include subjective average natural disaster fatality risk. Regressions adjust for sample weights.

+ significant at $10 \%$ level, * significant at $5 \%$ level, ** significant at $1 \%$ level; two-tailed test. 
Table 8. Preference for Government Assistance for Terrorism Losses by Subjective Personal Level of Terrorism Fatality Risk

\section{Assist victims of terrorist attacks}

Subjective personal level of terrorism fatality risk

\begin{tabular}{lcccccc} 
& \multicolumn{2}{c}{$\begin{array}{c}\text { Below-average } \\
\text { fatality risk }\end{array}$} & \multicolumn{2}{c}{$\begin{array}{c}\text { Average } \\
\text { fatality risk }\end{array}$} & \multicolumn{2}{c}{$\begin{array}{c}\text { Above-average } \\
\text { fatality risk }\end{array}$} \\
& Number & Percent & Number & Percent & Number & Percent \\
\hline No & 155 & 28.4 & 69 & 15.5 & 23 & 26.7 \\
Yes & 390 & 71.6 & 377 & 84.5 & 63 & 73.3 \\
\hline
\end{tabular}

Assist insurance companies

Subjective personal level of terrorism fatality risk

Below-average fatality risk
Average fatality risk
Above-average fatality risk

\begin{tabular}{lcrcccc} 
& Number & Percent & Number & Percent & Number & Percent \\
\hline No & 280 & 51.4 & 204 & 45.7 & 32 & 37.2 \\
Yes & 265 & 48.6 & 242 & 54.3 & 54 & 62.8 \\
\hline Observations & 545 & 100.0 & 446 & 100.0 & 86 & 100.0 \\
\hline
\end{tabular}


Table 9. Ordered Probit Regressions for Government Relief for Terrorism Losses ${ }^{\text {a }}$

\begin{tabular}{|c|c|c|}
\hline Independent Variables & $\begin{array}{c}(1) \\
\text { Terrorism } \\
\text { victims } \\
\end{array}$ & $\begin{array}{c}(2) \\
\text { Insurance } \\
\text { companies }\end{array}$ \\
\hline Age & $\begin{array}{l}-0.011^{* *} \\
(0.003)\end{array}$ & $\begin{array}{l}-0.011^{* *} \\
(0.003)\end{array}$ \\
\hline Female & $\begin{array}{c}0.198+ \\
(0.106)\end{array}$ & $\begin{array}{c}0.184+ \\
(0.096)\end{array}$ \\
\hline Black, non-Hispanic & $\begin{array}{c}0.570^{*} \\
(0.229)\end{array}$ & $\begin{array}{c}0.135 \\
(0.165)\end{array}$ \\
\hline Other/multiple race, non-Hispanic & $\begin{array}{c}0.042 \\
(0.266)\end{array}$ & $\begin{array}{c}0.096 \\
(0.248)\end{array}$ \\
\hline Hispanic, all races & $\begin{array}{c}0.209 \\
(0.203)\end{array}$ & $\begin{array}{c}0.110 \\
(0.158)\end{array}$ \\
\hline Mid-Atlantic & $\begin{array}{c}0.338 \\
(0.294)\end{array}$ & $\begin{array}{c}0.317 \\
(0.254)\end{array}$ \\
\hline East-North Central & $\begin{array}{l}-0.060 \\
(0.301)\end{array}$ & $\begin{array}{l}-0.074 \\
(0.252)\end{array}$ \\
\hline West-North Central & $\begin{array}{l}-0.271 \\
(0.327)\end{array}$ & $\begin{array}{l}-0.067 \\
(0.285)\end{array}$ \\
\hline South Atlantic & $\begin{array}{l}-0.121 \\
(0.277)\end{array}$ & $\begin{array}{c}0.162 \\
(0.242)\end{array}$ \\
\hline East-South Central & $\begin{array}{l}-0.205 \\
(0.315)\end{array}$ & $\begin{array}{l}-0.087 \\
(0.273)\end{array}$ \\
\hline West-South Central & $\begin{array}{l}-0.152 \\
(0.306)\end{array}$ & $\begin{array}{l}-0.192 \\
(0.267)\end{array}$ \\
\hline Mountain & $\begin{array}{c}0.068 \\
(0.307)\end{array}$ & $\begin{array}{l}-0.221 \\
(0.265)\end{array}$ \\
\hline Pacific & $\begin{array}{c}0.034 \\
(0.285)\end{array}$ & $\begin{array}{l}-0.151 \\
(0.248)\end{array}$ \\
\hline Metropolitan residence & $\begin{array}{c}0.195 \\
(0.134)\end{array}$ & $\begin{array}{c}0.161 \\
(0.126)\end{array}$ \\
\hline Years of education & $\begin{array}{l}-0.041+ \\
(0.025)\end{array}$ & $\begin{array}{l}-0.040+ \\
(0.022)\end{array}$ \\
\hline Household income & $\begin{array}{l}-0.016 \\
(0.017)\end{array}$ & $\begin{array}{l}-0.010 \\
(0.016)\end{array}$ \\
\hline Household income, top category & $\begin{array}{c}0.051 \\
(0.435)\end{array}$ & $\begin{array}{c}0.167 \\
(0.409)\end{array}$ \\
\hline
\end{tabular}




\begin{tabular}{lcc} 
Republican & $-0.298^{* *}$ & -0.101 \\
& $(0.110)$ & $(0.101)$ \\
Current smoker & $0.326^{*}$ & 0.095 \\
& $(0.136)$ & $(0.114)$ \\
More than 6 plane trips per year & 0.356 & 0.069 \\
& $(0.327)$ & $(0.265)$ \\
Above-average terrorism fatality risk & $-0.643^{* *}$ & -0.085 \\
& $(0.211)$ & $(0.182)$ \\
Below-average terrorism fatality risk & $-0.408^{* *}$ & -0.124 \\
& $(0.115)$ & $(0.101)$ \\
Constant & $1.955^{* *}$ & $0.923^{*}$ \\
& $(0.480)$ & $(0.403)$ \\
Observations & 1077 & 1077 \\
\hline
\end{tabular}

${ }^{a}$ Coefficient estimates (and standard errors in parentheses) from probits on indicator variables given in each column, where 1 indicates individual chose "yes" in answer to the pertinent terrorism assistance equation. Regressions adjust for sample weights. Excluded categories in regressions include subjective average terrorism fatality risk.

+ significant at $10 \%$ level, * significant at $5 \%$ level, ** significant at $1 \%$ level; two-tailed test. 
Appendix

Table A.1. Descriptive Statistics, Means and Standard Deviations of the Variables

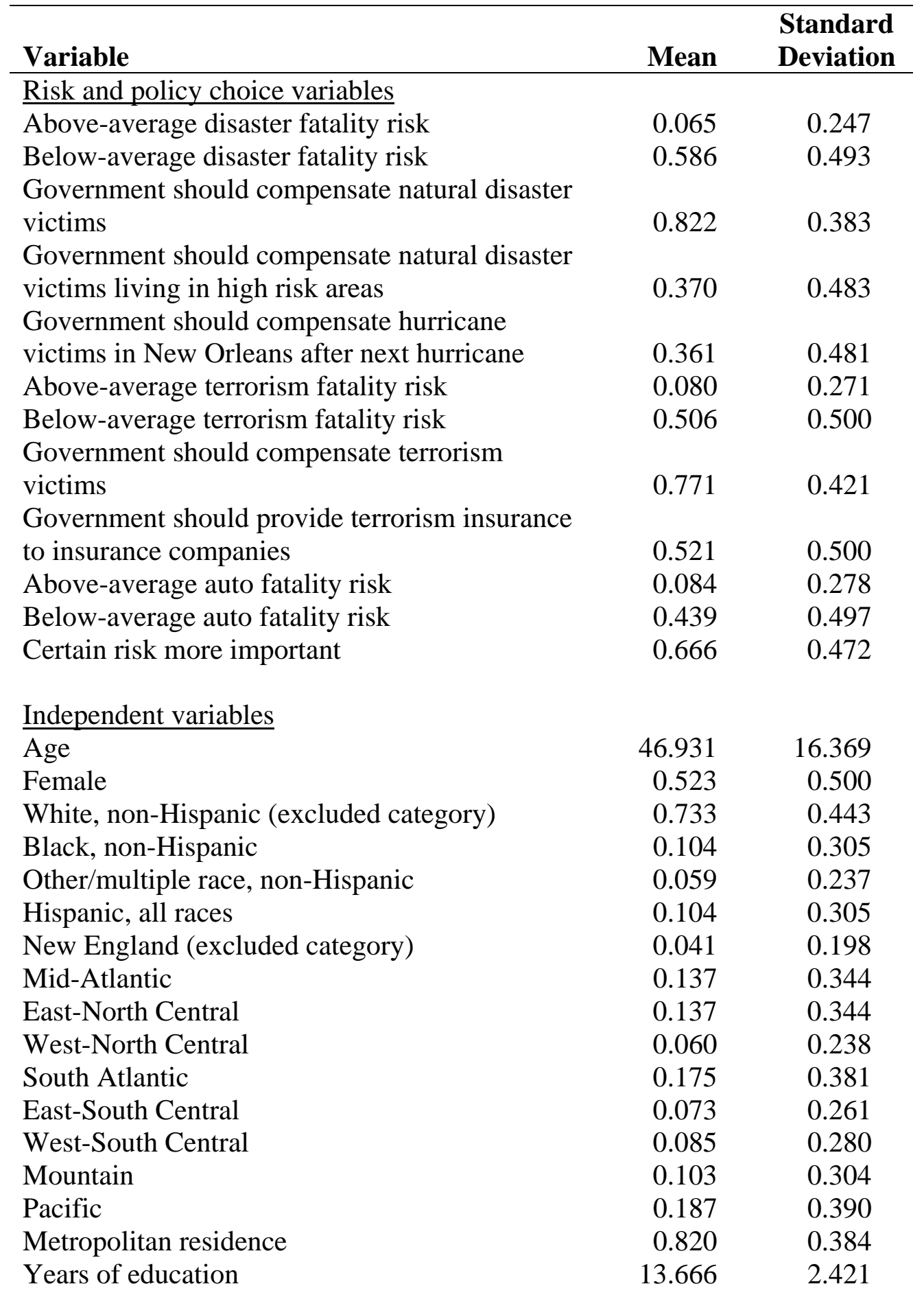


Household income, in tens of thousands of dollars

$5.086 \quad 3.740$

Household income, top category

$0.018 \quad 0.132$

Republican

$0.427 \quad 0.495$

Current smoker

$0.232 \quad 0.422$

Experienced natural disaster

$0.643 \quad 0.479$

Experienced hurricane

$0.263 \quad 0.440$

Experienced flood

$0.262 \quad 0.440$

Experienced earthquake

$0.266 \quad 0.442$

Experienced tornado

$0.298 \quad 0.458$

More than 6 plane trips per year

0.036

0.187

Observations

1,077 


\section{Table A.2. States in Each Census Division}

New England

(excluded category)

Mid-Atlantic

East-North Central

West-North Central

South Atlantic

East-South Central

West-South Central

Mountain

Pacific
Connecticut, Maine, Massachusetts, New Hampshire, Rhode Island, Vermont

New Jersey, New York, Pennsylvania

Indiana, Illinois, Michigan, Ohio, Wisconsin

Iowa, Nebraska, Kansas, North Dakota, Minnesota, South Dakota, Missouri

Delaware, Florida, Georgia, Maryland, North Carolina, South Carolina, Virginia, West Virginia

Alabama, Kentucky, Mississippi Tennessee

Arkansas, Louisiana Oklahoma, Texas

Arizona, Colorado, Idaho, New Mexico, Montana, Utah, Nevada, Wyoming

Alaska, California, Hawaii, Oregon, Washington 